\title{
Examination of Theoretical and Empirical Studies on Firm's Performance in Relation to its' Board Size: A Study of Small and Medium Size Public Firms
}

\author{
Jibran Sheikh \\ Department of Management Sciences \\ COMSATS University of Information Technology \\ Islamabad, Pakistan \\ E-mail: jibransheikh@comsats.edu.pk \\ M. Majid Khan, Ph.D \\ Department of Management Sciences \\ COMSATS University of Information Technology \\ Islamabad, Pakistan \\ E-mail: majidkhan799@comsats.edu.pk
}

\author{
Waheed Iqbal \\ Department of Management Sciences \\ COMSATS University of Information Technology \\ Islamabad, Pakistan \\ E-mail: waheed.iqbal@comsats.edu.pk \\ Wajid Shakeel Ahmed \\ Department of Management Sciences \\ COMSATS University of Information Technology \\ Islamabad, Pakistan \\ E-mail: wajid_shakeel@comsats.edu.pk
}


Muhammad Tahir Masood, Ph.D., P.E. (Corresponding author)

Professor, Department of Management Sciences

COMSATS University of Information Technology

Islamabad, Pakistan

Tel: 11-92-342 -5522-342Ｅ-mail: dr.tahirmasood@comsats.edu.pk

Received: March 12, 2012

Accepted: March 30, 2012 Published: April 1, 2012

doi:10.5296/jmr.v4i2.1504

URL: http://dx.doi.org/10.5296/jmr.v4i2.1504

\begin{abstract}
This research presented a review of key theoretical and empirical studies on firm's performance and its board size. The review included on small \& medium sized and public owned firms from manufacturing to financial sectors. The research concludes that the evidence on positive or negative correlation between board size and a firm's performance is mixed (inconclusive) and need for further empirical investigation on this subject is warranted. It was found that the choice of optimal board size can vary in one firm to other, depending on nature of business operations, i.e. for high debt-financed firms with high advisory requirements may require large board to advise CEO on complex matters, as does the banking and saving \& loans holding companies where more of expert advice, diversified opinions, professional skills are needed. Also, the firms with poor operating performance may increase their board size as one of their strategy to improve profitability given that new board members will contribute in the form of increased networking, skills, opinion and expert advice.
\end{abstract}

Keywords: Performance, Board Size, Business Operations, Strategy 


\section{Introduction}

The evaluation of relationship between a firm's board size and performance is not a new subject of debate in contemporary corporate finance literature. The earliest work on this subject was initiated by Lipton and Lorch (1992) where they argued that small numbers of directors can conveniently communicate, coordinate and collaborate with each other which can lead to low cost and downsizing. Also, the idea of small board eventually smoothens the decision making process in key investment and strategic policies. Lastly, they suggested that large number of board size may give rise to agency problems and also may strengthen the authority of CEO since it will be far easy for him to control, monitor and supervise the few directors. The large board may end up having exhaustive and inconclusive discussions and meetings on core company's policies and procedures (Lipton and Lorch, 1992).

The theory of negative correlation between small board size and firm's corporate performance was also supported by some other academicians, i.e.Hermalin and Weisbach (1991), Jenson (1993), Yermack (1996), Eisenberg et al. (1998). The argument of negative affiliation between board size and performance was empirically tested by various scholars of finance literature who reported element of negative association between board size and performance; see, for example, Yermack (1996), Eisenberg, Sundgren and Wells (1998) and Barnhart and Rosenstein (1998). Among these, the remarkable work of Yermarck (1996) is a key to support negative association where he performed regression on a sample date of more than 450 U.S. firms from 1984 to 1991. He used different combinations of regression parameters including Tobin's Q to precisely measure the level of negative association between board size and performance, which all showed the similar results of negative correlation.

The similar results were also shown by Eisenberg, Sundgren and Wells (1998) where they found significant negative association between board size and a firm's performance. Further, the empirical tests by Barnhart and Rosenstein (1998) also showed the identical outcome that firms with small board size performed better than having larger board size. Another interesting study by Vafeas (2000) suggested that where the size of board is limited to up to five members, it provides greater opportunity to be well informed of firms internal profitability matters thus giving better chance to monitor firm's activity which eventually would result in higher performance.

On the contrary, the other school thought argued that increase in number of board directors can provide more opportunities for networking, planning, expert advice, diversified opinions and more skilled managers which results in superior performance, see for example, Kiel and Nicholson (2003), Adam and Mehran (2005) and Dalton and Dalton (2005), etc. Furthermore, larger boards are more likely to be associated with an increase in board diversity in terms of experience, skills, gender and nationality. The counterargument of positive association between board size and performance was also empirically tested by Mak and Li (2001) and Adams and Mehran (2005) and Belkhir (2009), which showed evidence in support of large board size with higher performance. The work of Adam and Mehran (2005) which composed of Tobin's Q type measure of firm's performance showed evidence in favour of large board size linked with higher performance. 


\section{Literature Review}

\subsection{Agency Theory}

The previous academic literature on board size and performance stems from the fundamental principal-agent theory. The agency theory stipulates that principal (owner) and agent (manager) working for the same firm may not have similar interests though the agent might originally be hired to increase the shareholders value. Berle and Means (1932) were the first who discussed principal-agent dilemma in their thesis, "The Modern Corporation and Private Property." In their legendary work, they described the agency problem in detail that how conflicts of interests may arise in firms when managers' personal interests override their obligations to comply with principal-agent-contract of 'maximising the shareholders' wealth.' Dalton, Daily, Ellstrand and Johnson (1999) and Shleifer and Vishny (1998) also discussed the notion of agency theory and its relation and implications in determining the performance of a firm relative to its board size.

The conflicts of interests among managers and owners in publicly listed companies becomes more critical since shareholders desire to increase in their wealth whereas managers wish to keep a close control in company affairs and are more interested in increasing their personal wealth. Berle and Means (1932), Jensen and Meckling (1976) and Kaplan and Minton (1994) have discussed the agency theory in length in their remarkable work. Fama (1980) on agency theory argued that board of directors are key to monitor, supervise and coordinate with managers and that board size, its structure and leadership are central to keep a check on managers' activity.

\subsection{Empirical Observations on Agency Theory}

The empirical evidence on incentive-lead high performance of workers is rather strong. The higher perks and benefits for directors may logically lead to higher performance and motivation. The most of the studies were performed on incentive-driven performance of employees. As a general rule, attractive incentive schemes will motivate the employees to perform better which eventually would lead to higher productivity. A study by Lazear (2000) shown that the level of productivity rose up to $44 \%$ from a change to fixed salary to performance-related incentives.

The similar results were also shown by Paarsch \& Shearer (1996) where they found a significant pattern of high productivity in a performance-driven payroll framework. The studies performed by Banker, Lee, and Potter (1996) and Fernie and Metcalf (1999) also found the same results where performance was higher in employees for organization with productivity-driven enticement.

A study on Chinese industry focusing on workers performance with change in payroll matrix by McMillan, Whalley and Zhu (1989) found a significant association between perks and productivity. Another interesting study by Kahn and Sherer (1990) mainly directing to productivity of employees working in white-collar jobs. Their study also indicated a steep positive correlation between performance and incentives of office workers.

\subsection{Analysis of Board Size and Performance}

The prior studies on board structure and a firm's performance may broadly be divided in two main categories; (i) - how performance of a firm is affected by size of board in discrete affairs of business, (ii) - evaluating the level of correlation between board size and a firm's performance (see Bhagat \& Black, 1999). The first approach involves assessing the impact of 
board structure in designing and implementing long-term business strategies, i.e. making or stopping a acquisition bid, appointment of CEO or offering golden-hand shake awards. It has been argued that firms operating under independent board directors due to having complete autonomy in making decision, such as, hiring or terming the CEO. Weisbach (1988) reported significant evidence on board autonomy and positive performance. Furthermore, a study by Byrd \& Hickman (1992) found that independent boards make and/or resist successfully making or avoiding takeover bids.

The second approach involves focusing entirely on précising measuring the degree of correlation between a firm's performance and its composition (size) of board (Bhagat \& Black, 1999). The earliest work on board size and performance by Vance (1964) found strong association (correlation) between performance and composition of board. However, on contrary, few past studies by MacAvoy, Cantor, Dana and Peck (1983), Baysinger and Butler (1985), Hermalin and Weisbach (1991) reported no significant correlation. Other academicians such as Eisenberg et al. (1998), Hermalin and Weisbach (1991) Jenson (1993), Monks and Minow (1995), Yermack (1996) Sundgren and Wells (1998) and Barnhart and Rosenstein (1998) also support the theory of negative correlation.

Among these Yermarck (1996) is keen supporter of negative co relation. He tested this theory on the data of than 450 U.S. firms from 1984 to 1991. His regression parameters included Tobin's Q measure to pin point the correlation between performance and board size and his study showed negative relationship.

A study by Vafeas (2000) suggested that the optimum number (size of the board) should be five. The results showed that in this case, the directors were well informed about the internal (profitability) matter of which in turn resulted in better performance. On the other hand Kiel and Nicholson (2003), Adam and Mehran (2005) and Dalton and Dalton (2005), etc. argue that large borad size increases the diversity in terms of experience, skills, gender, style of management and nationality. This improves overall planning, expert advice, diversified opinions and more skilled managers which results in superior performance. Mak and Li (2001) and Adams and Mehran (2005) showed evidence in support of large board size with higher performance.

Similarly, Coles et al. (2008) suggest that complex firms their study showed significant positive relationship amongst the board size and performance of the firms. The results were consistent with the findings of Adam and Mehran (2005). Di Pietra's research also showed similar results Di Pietra'et al. (2008).

\subsection{Perspectives on Market Valuation of Firms with Small Board Size}

Yermack (1996) investigated firm's value and board size and the significance of this study was the data set and measure. The sample data in his study consisted of 500 largest companies ranked in Forbes magazine based on their sales, market capitalization, net profit and total assets. He included total of 3,438 observations on 452 companies over a period of 8 years for analysis.

He employed Tobin's-Q measure estimate in regression analysis. The set of explanatory variables included, i.e. a firm size, board size, industry type, and historical performance of the company. Yermack backed consisted with the earlier hypothesis suggested by Lipton \& Lorsch (1992) and Jensen (1993). The regression measure used by Yermack was based on earliest techniques used by Morck, Shleifer, and Vishny (1988), Hermalin and Weisbach (1991), and Lang and Stulz (1994). 
However, when we consider the fact that large diversified company will have large board as these firms will frequently engage in merger \& acquisition activities, which may make the findings of regression analysis bias. Yermack (1996) included an additional variable to show the impact of total numbers of business segments included in portfolio. He included two additional variables into regression model to incorporate the impact of boards with high stock ownership and directors from outside the firm (NED).

\subsection{Analysis Of Impact of Board Size on Financial Ratios}

In essence, Yermack (1996), concluded that increase in size of board would lead to a decline in efficient use of assets declines, thus lowering the financial ratios. As result investors generally would appreciate a decrease in board size and thus valuing the stock higher. He backed up his claim by stating the fact that out of every six announcements for reduction in board size, on five occasions the firm's earned abnormal returns. And, four out of six announcements on expansion in board size showed negative returns. Another interesting finding of this study showed an element of insider information based on accumulation of abnormal returns two weeks earlier before the announcement dates. So he claimed that smaller board can manage the affairs of companies in a better way. He found no evidence that suggested that companies changed board composition in response to historical poor performance.

\subsection{Linkages between Large Board Size and Firm's Value}

Eisenberg et al. (1998) has further discussed the findings of Yermack (1996) study. He stated that Yermack's results lacked consistency as Eisenberg et al. (1998, p - 2) were sceptical of factual evidence presented by Yermack (1996). In order to overcome this shortcoming, Eisenberg et al. employed sample dataset of random 900 (785 alive and 94 bankrupt firms) small firms from 1992 to 1994. The addition of bankrupt firms in sample allowed to evaluate the reasons of bankruptcy if it was mainly due to board size which resulted in lower performance and thus leading towards bankruptcy. They argued that this would remove the criticism regarding ownership as in case of small and medium size firms, ownership was closely held, there were less agency issues.

Eisenberg et al. (1998) based their findings on return on assets measure but they used industry median instead of industry mean average. They found substantial abnormal returns on investment for firms with small board size. Although many explanations were presented to justify the abnormal returns amongst these one was if past performance of company is not satisfactory firms will decrease their board members (Jensen, 1993). Another explanation for higher returns with small board was "evolving nature of the firm." This idea is based on the argument that evolving nature of board is the result of changing firm structure.

Well, this study incorporated few additional parameters which were neglected in Yermack (1996) study like inclusion of small unlisted firms, the situation where bank officers are part of board members etc. (see Eisenberg et al., 1998, p - 17 for details).

In terms of agency theory viewpoint, this study outlined the fact that firms are effects size of boards even if they are closely held. Moreover, there is no ideal size of board as it varied with nature of business and industry in which it operates.

\subsection{Relevance of Board Size}

A key study on board size and performance by Coles et al. (2008), evaluated the impact of board size on firms with higher advisory requirements. The primary idea on this study was to 
analyse that the largely diversified firms with higher debt financing are complex in nature and have more advising requirements and how these determine their board size. The basic argument in favour of large board is put forward that increase in number of board directors can provide more opportunities for networking, planning, expert advice, diversified opinions and more skilled managers which results in superior performance, see for example, Dalton et al. (1999), Kiel and Nicholson (2003), Adam and Mehran (2005) and Dalton and Dalton (2005). Thus, the size of board in such complex firms should be larger based on earlier argument on benefits of large board size. Moreover, majority of directors for these firms should be outsiders so that expert advice, knowledge and experience can be shared with CEO (Hermalin and Weisbach, 1988, Agrawal and Knoeber, 2001and Fich, 2005).

This study used a total of 8,165 observations over a period of 1992 to 2001 taken from Compact Disclosure and Investor Responsibility Research Center (IRRC). The study employed similar performance related regression methodology where Tobin's Q measure is explained variable, similar to used in Yermack (1996) study.

The conclusion from the study showed contrary evidence to Yermack (1996) study, which suggested a positive relation between board size and performance with high advising requirement firms opposite to Yermack findings where he documented a strong negative correlation between board size and performance.

The results showed a positively associated Tobin's Q measure to board size. Furthermore, converse to Yermack (1996) evidence where it was argued that smaller boards are more independent which smoothens the communication and decision making process, eventually increasing the firm value, this study showed that complex type of firms with higher advisory requirements are better off with large board size.

Also, this study demonstrated that the larger proportion of board size for firms with high Research \& Development (R\&D) requirements come from insiders, which are consistent with earlier findings of Hermalin and Weisbach (1988).

Lastly, the study validated the earlier evidence proposed by Adams and Ferreira (2007), Adams and Mehran (2005), and Agrawal and Knoeber (2001) on positive association between board size and firm's performance for firms with higher advisory requirements for board members.

\subsection{Examination of Board Size \& Firm's Performance in Banking Industry}

The majority of studies on board size and performance are centred on manufacturing firms. The composition of board in banking industry because of it is tightly regulated unlike manufacturing industries. Belkhir (2009) conducted his study on banking industry of U.S.by taking sample data

(Tobin's Q = BV of Total Assets - BV of Equity + MV* of Equity Book Value* of Total Assets)

set of 174 banking, holding, saving and loans companies with book value of over $\$ 1$ billion. He included 1,150 observations from 1995 to 2002. He used Tobin-Q and Return on Assets measures and panel dataset techniques. He modified the Tobin's Q equation to following:

*BV is Book Value and MV is Market Value 
The Return on Asset (ROA) was computed using net income before exceptional items divided by book value of total assets. This study involved regression techniques and Univariate analysis, which were consistent with Yermack (1996).

The dummy variables were used to evaluate other hypothesis, likepast performance, evolving nature of firm, and change in board structure based on past performance.

The results contradicted the claims of Yermack (1996) and Eisenberg et al. (1998) as findings of this study did not show any evidence to support the hypothesis put forward by Lipton \& Lorsch (1992) and Jensen (1993). The results showed positive relation between board size and performance in the banking sector. The study validated the findings of Nicholson (2003), Adam and Mehran (2005) and Dalton and Dalton (2005).

\subsection{Board Size and Its Relation with Poor Operating Performance}

Larmou \& Vafeas (2010) evaluated the impacts of increasing board members for firms with poor operating performance. The main objective of the study was to evaluate whether or not change in board size has any effects on accounting profits of any firm or not. As accounting profits are less volatile when compare to equity prices. Because firms with poor performance are more likely to change their board structure and member in order to boost their performance.

Larmou \& Vafeas (2010) employed different measure to compute operating profits and also adjusted the measure for industry average.

$$
\text { Operating Profit = Operating Income before Depreciation (OIBDP) }
$$

\section{Book Value of Total Assets}

Larmou \& Vafeas (2010) used dummy variable regression model to overcome survivorship bias and industry bias. Also, they concluded that investors welcome the increase in board size, when performance of the firm is poor, as this increase resulted in higher returns.

\section{Summary}

In this paper we reviewed of key theoretical and empirical studies on corporate board size and performance of firms. The review included on small \& medium sized and public owned firms from manufacturing to financial industries. The earliest recognized theoretical work on this debate is known of Lipton and Lorch (1992) and Jensen (1993) who argued that small board size increases firm's performance and thus the value. Their argument was based on the notion that few board members can conveniently communicate, coordinate and collaborate and decision-making process is more smothering small size boards and large board may give rise to 'agency issue.' The element of strong negative association (correlation) between board size and performance was empirically tested and validated by Yermack (1996), Eisenberg et al. (1998), Barnhart and Rosenstein (1998), Hermalin and Weisbach (1991).

On the other hand, the proponents of achieving higher performance with large board size argued that higher number of directors will provide the business with opportunity to having better networking \& relationship with existing and potential clients, efficient planning, diversified views and more of expert opinions and advice, which will enhance firm's performance (see Kiel and Nicholson, 2003; Adam and Mehran, 2005; and Dalton and Dalton, 2005). This contrary view of positive correlation between board size and firm's performance was also empirically tested and validated by Dalton et al., (1999); Agrawal and Knoeber, 
(2001); Kiel and Nicholson, (2003); Adam and Mehran, (2005); Dalton and Dalton, (2005); Fich, (2005); Ferreira, (2007); Coles et al., (2008); Belkhir, (2009); and Larmou \& Vafeas, (2010).

Yermack (1996) and Eisenberg et al. (1998) studies found significant negative correlation between board size and performance. The sample data in Yermack and Eisenberg et al. studies included 500 largest (publicly listed) and small to medium sized firms, respectively. Both of these studies were comprehensive in nature based on Tobin's Q performance measure with dummy variables and event type regression analysis. However, some of key studies on positive relationship between board size and firm's value were performed on specific firms type or industry, such as, Coles et al. (2008) study on (high leveraged) firms with greater advisory requirements; Belkhir (2009) study on Banking Holding Companies (BHCs) and Saving and Loans Holding Companies (SLHCs); and Larmou \& Vafeas (2010) study on firms with poor operating performance.

Therefore, it may be argued that choice of optimal board size can vary in one firm to other depending on nature of business operations, i.e. for high debt-financed firms with high advisory requirements may require large board to advise CEO on complex matters, as does the Banking and Saving \& Loans Holding Companies where more of expert advice, diversified opinions, professional skills are needed. Nonetheless, for small \& medium sized firms and firms with manufacturing operations, etc. small size board may be desirable.

It is worth mentioning here that value of firms is determined by the investor views about firms and that opinion is influenced by announcements of increase/decrease in board size see Larmou \& Vafeas, (2010), a study on firms with poor operating performance where they found positive investors' response on increase of board size.

Lehn et al. (2004) argued that the size of board is positively linked to firm's size, thus larger the firm, large the board size. This study was performed over a period of 65 years (1935 to 2000) on 81 publically owned listed firms. The similar findings were presented by Linck et al. (2008) which showed increase in board size in line with size (growth opportunities) of firm.

\section{Conclusion}

To conclude it can be safely said that board size and performance of any company are deeply co-related. The extent of this co-relation depends upon the nature of the business and economic environment in which firm operates. When we talk about the optimum board size, well it more or less depends upon the level of the trade off which share holder are willing to keep up with. Most of time if performance of the company is improving the share holder might be willing to tolerate large board size and their compensations, while on the hand if performance of company goes down the share holder would raise the question about the board size. To be precise there is no optimum board size as one fits all policy cannot be applied to all firms. The simple reason is the nature, size, business environment and general economic conditions in which firms operate greatly differ from one another. What so ever the case one cannot refute the fact that size of the board has an impact on the performance of the company. This is not just stylised fact but is proven via study of the theoretical and empirical literature.

Firms may increase the size of the board as part of their strategy to improve the performance considering that new board members will contribute in the form of increased networking, skills, opinion and expert advice. Besides all of the arguments mentioned above we should 
not forget that that firms aim to obtain an equilibrium point of board size while simultaneously estimating a level of trade-off between costs and benefits of adding new directors to board Lipton and Lorsch (1992). This is one the reasons that evidence on positive or negative correlation between board size and a firm's performance are mixed at best.

The main limitation of this study is that here we have only analysed the available literature and the main aim was not to approve or disprove any theoretical or empirical study, but to provide an insight into the available literature for future research. It is recommended that in future, researchers could test the above mentioned theories on their local or regional economies, as each economy has different dynamics, different culture, and different regulations. Also, the evidence on positive or negative correlation between board size and a firm's performance is found to be mixed (inconclusive) and hence further empirical investigation on this subject is another avenue for future research.

\section{References}

Adams, R., \& Mehran, H. (2005). Corporate performance, board structure, and its determinants in the banking industry, working paper. Stockholm School of Economics.

Adams, R.B., \& Ferreira, D. (2007). A theory of friendly boards. Journal of Finance, 62, 217-250. http://dx.doi.org/10.1111/j.1540-6261.2007.01206.x

Agrawal, A., \& Knoeber, C. (2001). Do some outside directors play a political role? Journal of Law and Economics, 44, 179-198. http://dx.doi.org/10.1086/320271

Barnhart, S. W., \& Roseinstein, S. (1998). Board Composition, Managerial Ownership, and Firm Performance: An Empirical Analysis. The Financial Review, vol. 33, pp. 1-16. http://dx.doi.org/10.1111/j.1540-6288.1998.tb01393.x

Banker, R., Lee, S., \& Potter, G. (1996). Contextual Analysis of Performance Impacts of Outcome-Based Incentive Compensation. Academy of Management Journal, Vol. 39, No. 4, 920 - 948. http://dx.doi.org/10.2307/256717

Baysinger, Barry, \& Henry Butler. (1985). Corporate governance and the board of directors: Performance effects of changes in board composition. Journal of Law, Economics and Organization, 1, 101-124.

Belkhir, M. (2009). Board of Directors, Size and Performance in the Banking Industry. International Journal of Managerial Finance, Vol. 5, Issue 2, P. 201 - 221. http://dx.doi.org/10.1108/17439130910947903

Berle, A.A., \& Means, G.C. (1932). The Modern Corporation and Private Property. Commerce Clearing House, New York.

Bhagat, S., \& Black, B. (1999). The uncertain relationship between board composition and firm performance. Business Lawyer, 54, 921-963.

Byrd, J. W., \& Kent A. H., (1992). Do outside directors monitor managers? Journal of Financial Economics, 32, 195-22 1.

Cary, W., \& Eisenberg, M. (1995). Cases and Materials on Corporations. The Foundation 
Press, Inc., Westbury, NY.

Coles, J.L., Daniel, N.D., \& Naveen, L., (2008). Boards: does one size fit all? Journal of Financial Economics, 87, 329-356. http://dx.doi.org/10.1016/j.jfineco.2006.08.008

Dalton, C. M., \& Dalton, D. R. (2005). Boards of Directors: Utilizing Empirical Evidence in Developing Practical Prescriptions. British Journal of Management, vol. 16, pp. s91-s97. http://dx.doi.org/10.1111/j.1467-8551.2005.00450.x

Dalton, D., Daily, C., Johnson, J., \& Ellstrand, A. (1999). Number of directors and financial performance: a meta-analysis. Academy of Management Journal, 42, 674-686. http://dx.doi.org/10.2307/256988

Di Pietra, R., Grambovas, C., Raonic, I., \& Riccaboni, A. (2008). The effects of board size and "busy" directors on the market value of Italian firms. Journal of Management and Governance, 12, 73-91. http://dx.doi.org/10.1007/s10997-008-9044-y

Eisenberg, T., Sundgren, S., \& Wells, M. T. (1998). Larger board size and decreasing firm value in small firms. Journal of Financial Economics, 48, 35-54. http://dx.doi.org/10.1016/S0304-405X(98)00003-8

Fama, E.F. (1980). Agency problems and theory of the firm. Journal of Political Economy, 88, 288-307. http://dx.doi.org/10.1086/260866

Fernie, S., \& Metcalf, D. (1999). (Not) hanging on the telephone: Payment systems in the new sweatshop. Advances in Industrial Relations, 9, 23 - 68.

Fich, E. (2005). Are some outside directors better than others? Evidence from director appointments of Fortune 1000 firms. Journal of Business, 78, 1943-1972. http://dx.doi.org/10.1086/431448

Hackman, J. Richard, ed. (1990). Groups that work. Jossey-Bass, San Francisco, CA.

Hermalin, B., \& Weisbach, M. (1991). The effects of board composition and director incentives on firm performance. Financial Management, 20, 101-112. http://dx.doi.org/10.2307/3665716

Hermalin, B., \& Weisbach, M., (1988). The determinants of board composition. Rand Journal of Economics, 19, 589-606. http://dx.doi.org/10.2307/2555459

Jensen, M. (1993). The modern industrial revolution, exit, and the failure of internal control systems. Journal of Finance, 48, 831-880. http://dx.doi.org/10.2307/2329018

Jensen, M.C., \& Meckling, W.H. (1976). Theory of the firm: managerial behavior, agency costs and ownership structure. Journal of Financial Economics, 3, 305-360. http://dx.doi.org/10.1016/0304-405X(76)90026-X

Kaplan, S.N., Minton, B. (1994). Appointments of outsiders to Japanese boards: determinants and implications for managers. Journal of Financial Economics 36, 225-257. http://dx.doi.org/10.1016/0304-405X(94)90025-6 
Kiel, G.C., \& Nicholson, G.J. (2003). Boards that work: A new guide for directors. McGraw Hill, NSW Sydney.

Stulz, M., et al. (1994). Tobin's Q, corporate diversification, and firm performance. Journal of Political Economy, 102, 1248-1280. http://dx.doi.org/10.1086/261970

Larmou, S., \& Vafeas, N. (2010). The relation between board size and firm performance in firms with a history of poor operating performance. Journal of Management and Governance, 2010, vol. 14, issue 1, pages 61-85. http://dx.doi.org/10.1007/s10997-009-9091-z

Lazear, E.P. (2000). Performance pay and productivity. American Economic Review, 90, 1346 - 61. http://dx.doi.org/10.1257/aer.90.5.1346

Lipton, Martin, \& Lorsch J. W., (1992). A modest proposal for improved corporate governance. Business Lawyer, 48, no. I, 59 - 77.

MacAvoy, Paul W., Cantor S., Dana J., \& Peck, S., (1983). ALI proposals for increased control of the corporation by the board of directors: An economic analysis. In Statement of the Business Roundtable on the American Law Institute's Proposed "Principles of Corporate Governance and Structure:” Restatement and Recommendations, exhibit C-1.

McMillan, John, Whalley, Zhu, Lijing, (1989). The Impact of China's Economic Reforms on Agricultural Productivity Growth. Journal of Political Economy, University of Chicago Press, vol. 97(4), pages 781-807.

Mak, Y.T., \& Li, Y., (2001). Determinants of Corporate Ownership and Board Structure: Evidence from Singapore. Journal of Corporate Finance, 7, 235-256. http://dx.doi.org/10.1016/S0929-1199(01)00021-9

Monks, Robert, \& Nell M., (1995). Corporate governance. Basil Blackwell, Cambridge.

Morck, R., Shleifer, A., \& Vishny, R., (1988). Management ownership and market valuation: an empirical analysis. Journal of Financial Economics, 20, 293-315. http://dx.doi.org/10.1016/0304-405X(88)90048-7

Lawrence M. K., \& Peter D. S., (1990). Contingent pay and managerial performance. Industrial and Labor Relations Review, ILR Review, ILR School, Cornell University, vol. 43(3), pages 107-120.

Paarsch, H., \& Shearer, B., (2000). Piece rates, fixed wages, and incentive effects: Statistical evidence from payroll records. International Economic Review, 41, 59 - 92. http://dx.doi.org/10.1111/1468-2354.00055

Vafeas, N. (2000). Board Structure and the Informativeness of Earnings. Journal of Accounting and Public Policy, vol. 19, no. 2, pp. 139-160. http://dx.doi.org/10.1016/S0278-4254(00)00006-5

Vance, \& Stanley C., (1964). Board of directors: Structure and performance. Harvard Business School Press, Boston, MA. 


\section{Macrothink}

Journal of Management Research ISSN 1941-899X 2012, Vol. 4, No. 2

Weisbach, \& Michael, (1988). Outside directors and CEO turnover. Journal of Financial Economics, 20, 43 I-460.

Yermack, D. (1996). Higher market valuation of companies with a small board of directors. Journal of Financial Economics, 40, 185-212. http://dx.doi.org/10.1016/0304-405X(95)00844-5 